\title{
The Effect of Two Types of Corrective Feedback on EFL Learners' Writing Skill
}

\author{
Sina Soltanabadi Farshi (corresponding author) \\ Department Of English, Tabriz Branch, Islamic Azad University, Tabriz, Iran \\ E-mail: sina.pasha92@gmail.com \\ Saeedeh Khalili Safa \\ Department Of English, Tabriz Branch, Islamic Azad University, Tabriz, Iran
}

Doi:10.7575/aiac.alls.v.6n.1p.26

URL: http://dx.doi.org/10.7575/aiac.alls.v.6n.1p.26
Received: 09/09/2014

Accepted: 10/11/2014

\begin{abstract}
The purpose of this study was to compare the effects of two types of corrective feedback on EFL learners' writing skill. Thirty five advanced learners in three groups participated in this study. Structures of written texts were taught in all three classes during fourteen sessions of treatment; and each session, a related topic was given and the learners were asked to write about it. In class A, the learners had to deliver their assignments to the teacher in classroom; then the teacher wrote the corrective notes on their papers and gave their papers back the next session. In class B, students had to write their assignments on their electronic instruments, and after that send written tasks via email to the teacher, and he also sent the corrective comments on their errors through email. In class $\mathrm{C}$, as control group, no corrective feedback was given to learners' errors in their written tasks. Moreover, in class C, learners were free to deliver their writings whether in class or by email. The obtained results showed both methods to be effective since the scores of both experimental groups were significantly higher than the scores of control group, but electronic feedback was more effective and profitable than traditional type; because scores of the learners in group B (Electronic feedback) were significantly higher than class $\mathrm{C}$ (Traditional feedback).
\end{abstract}

Keywords: writing skill, corrective feedback, electronic feedback, traditional feedback

\section{Introduction}

Among the major issues raised by classroom SLA research is the controversial question of whether and how to include grammar in second language classrooms (Doughty and Williams, 1998). The early approaches and methods of language teaching, such as Audiolingual method, have emphasized the role of accuracy and have mentioned that errors should be avoided at all costs( focus on formS). On the other hand, there are more communicative approaches and methods for teaching languages, such as Communicative Language Teaching (CLT), which have just emphasized the role of fluency in using the language and proponents of these methods have mentioned that the ultimate goal of language learning is the achievement of an affective level in interpersonal relationships and conduct, i.e., language is viewed as a means of expressing values and judgments about oneself and others and as a means of expression as well. During the history of language teaching, however, it has been proved that the first set of methods, focusing grammar as a primitive aim of language learning curriculum, accuracy preclude fluency. That is, if the only focus is on grammatical accuracy, then the students will not be able to use the language fluently in real contexts. To the latter set of methods, teachers and researchers have found that learners lack accuracy in using language. According to Fotos (1998) 'purely communicative instruction alone is equally inadequate as long as grammatical instruction is neglected.' Considering these two theoretical extremes, both theories have their own merits and deficiencies. It is now the crucial issue for foreign language teachers to develop effective teaching strategies to balance both meaning and form. To do so, Long (1991) proposed Focus on Form (FonF) instruction as a medium to focus on formS and pure communicative approaches. Long and Robinson (1998, p.23) define FonF as "an occasional shift of attention to linguistic code features - by teacher and/or one or more student - triggered by perceived problems with comprehension or production". However, according to Ellis, Basturkmen, and Loewen, (2001) we should stick in mind that with form in FonF instruction, just grammar is not intended and it can be aimed to phonology, vocabulary, discourse, grammar, or even spelling.

The essence of FonF is clear when it is viewed as an influential element in focusing learners' attention on features of the L2. Thus, teachers can use different types of FonF to teach and draw learners' attention to target language forms; i.e., implicit or explicit. As mentioned earlier, Long (1991) defined FonF as the traditional way of teaching linguistic elements such as structures, notions and lexical items where language is treated primarily as an object to be studied and practiced. He noticed three major characteristics of FonF: firstly, the learner should be engaged in meaning to precede attention to the code; secondly, the importance of analyzing learners' linguistic needs to identify the forms that require treatment, and thirdly, the need for the treatment to be brief (Doughty and Williams, 1998). It also should be mentioned 
that in both cases the level of awareness is necessary and sufficient for converting input to intake. According to Schmidt (1990, 1993 and 1994) learners must first show a conscious perception and awareness of some particular form in the input before any subsequent processing of that form can take place. Another way of focusing on form is to do so after some errors are noticed in the process communication or doing tasks from learner's end. The reaction that teacher shows to the errors in the later type, is referred to as Corrective Feedback (CF), which was the central scope of this research. Lightbown and Spada (1999), define CF as "an indication to the learners that his or her use of the target language is incorrect". Teachers do so when there is a difficulty or disorder trouble/difficulty in conveying the intended meaning. When we come to writing skill, teachers can provide CF in different ways when errors are noticed in the hand writings of the learners. Learners can be provided with CF whether directly or indirectly; in this case, as Ellis, Sheen, Murakami, and Takashima (2008) found, it is better to give direct CF, in which the teacher himself directly correct the errors, only when specific type of error is salient in the leaner's hand writing.' They can also use endnotes, textual corrections, or locate the errors. One factor that affects the degree of explicitness is the error and its type. If so, we have to pay attention to type and saliency of the error in the hand writing samples of the learners. Also, it has been found that overlooking some errors will encourage the learners to communicate more fluently. Needless to say, minor errors that do not interfere the meaning are better to be overlooked.

The current study aimed to compare two types of providing corrective feedback to the written texts by the learners, hand written and electronic feedback. On one hand, in the case of traditional hand written feedback provided by teacher, learners give their writing samples to their teacher in the classroom and few days later, the teacher gives the papers back to them with some direct correction or comments about the errors. On the other hand, electronic feedback exists. Nowadays, with regard to the deployment of using personal computers by learners, the key role of these instruments in language learning process is inevitable. One of the most prevalent applications of computers in language learning process is e-mail. Learners can contact and communicate their peers and even their teachers at any time and even more easily; by doing so, the distance between learners and teachers becomes much closer than past. Hence, to writing skill, the integration of technology and language learning shows itself in terms of electronic feedback. Many researchers suggest numerous benefits of electronic feedback in educational domain, such as greater levels of participation (Gonza'lez-Bueno, 1998), more motivation and interest (Skinner \& Austin, 1999 as cited in Shang, 2007), reducing anxiety (Kupelian, 2001as cited in Shang, 2007), language functions (Wang, 1998 as cited in Shang, 2007), and etc. Taking these beneficial aspects of using computers into account, it seems that using these tools can be useful and beneficial in language learning. In this type, one way is that the teacher gives a topic and asks the learners to write about it on their electronic instruments (i.e., PC, laptop, tablet, cell phone and etc.), and send their assignments via e-mail to their teacher, and then the teacher reads them, notes the needed comments or corrections, and then sends it back to the learners.

In addition to these theoretical views, some empirical studies have been done to examine the effectiveness of these two types of feedback in several aspects. In a study conducted by Koolivand and Iravani (2013) among forty EFL learners in a writing course, they found that students who received electronic corrective feedback made greater improvement than learners to whom the feedback was provided in traditional type. Similarly, Tuzi (2001) reported that students who received online feedback through computer could write better texts after a course of instruction.' In his research, the participants were intermediate an advanced learners of English in two groups; where the first group received traditional handwritten feedback, and the second group received electronic feedback by the means of computer.

However, the opposite has also been found. Matsumara and Hann (2004) concluded that traditional hand written feedback by teacher is more effective than electronic feedback in conjunction with learners' writing skill. They also found that the amount of interaction and feedback provided in the traditional type is much greater than the electronic one. In another research, Sauro (2009) has found no significant difference between traditional feedback and the electronic one in the case of writing skill. His participants were twenty three upper intermediate and advanced learners of English in two experimental and one control group. However, it is worth to notice that he has reported both types of feedback to be effective, but none of them is superior to the other.

Since few research have been done in this particular field, still there is a gap and teachers often get confused whether to use electronic or traditional version in the process of providing learners with corrective feedback in the case of their written errors. Moreover, most of the past studies have concentrated on the effectiveness of one kind of corrective feedback on different skills and sub-skills. Hence, this study was an attempt to reexamine the effectiveness of these two types of giving corrective feedback and find out which type outdo the other; Consequently, it was aimed at helping teachers to confirm or change their views toward second language writing. Taking these points into account, the research question of this study was as follows:

RQ) Whether and to what extent traditional hand written corrective feedback and electronic corrective feedback through email affect the writing skill of English language learners?

\section{Methodology}

\subsection{Participants}

Thirty five advanced EFL students participated in the current study in three different classes in a language institute in Tabriz, Iran. Their ages were ranging from twenty one to thirty six, and their first language was Azeri Turkish. In class A $(\mathrm{N}=13)$, traditional hand written type corrective feedback was used to respond to the errors noticed in the learners' written drafts. In class $\mathrm{B}(\mathrm{N}=11)$, the electronic type of corrective feedback was employed to react to the errors of the 
learners. In addition, in the case of class $\mathrm{C}(\mathrm{N}=11)$, which was considered as the control group, no attempt was made to react to the errors of the learners in their written tasks. Furthermore, the results obtained from proficiency test, indicated that all three groups were approximately at the same level of proficiency.

\subsection{Instruments}

To accomplish the objectives of the study, a pre-test and post-test of writing was developed and administered to all three classes before and after the treatment. In each of these tests, three topics were given to the learners and they were asked to write a paragraph about only two topics. In order to estimate the reliability of the scores obtained from both tests, the written texts by the learners were scored by three experienced raters (inter-rater reliability). In the case of pretest, the correlation among the scores of the three raters came to be .81, and in terms of post-test, it found to be .79 . Moreover, KET proficiency test, which is advised for the advanced learners, was employed and administered to all three groups before the treatment to minimize the effects of differential proficiency levels on the results.

\subsection{Design}

The current study had two independent variables (traditional hand written corrective feedback, and electronic corrective feedback), and a dependent variable (writing skill of the learners). This work has been done in quasi-experimental mode through the employment of two different kinds of treatment for two experimental groups; while the other group was considered as control group. For class A, the corrective feedback was provided through traditional hand written type, while for class B, the other experimental group, corrective feedback was provided to the learners via email by the medium of computer. For class $\mathrm{C}$, as a control group, the learners were free to submit their writings in class or via email to their teacher.

\subsection{Procedure}

The present research was conducted in three different classes, where the classes took place two times a week and the researcher himself was the teacher of all three classes. Before starting the treatment, a proficiency test (KET) was given to all of the participants; and the results revealed that they were more or less at the same level of English language proficiency. Next, a pre-test of paragraph writing was administered to the students in the three classes. Afterwards, in treatment stage, which lasted fourteen sessions, in class A, the teacher described the different genres of paragraph writing and gave them a topic, and then asked them to write a paragraph about the topic which was related to the newly learnt genre for the next session. The teacher read them and then provided different types of corrective feedback on the paper according to the type of error and its frequency. Afterwards, the students were asked to revise their texts on the basis of the notes provided by the teacher on their papers.

For class B, the same type of explanation about the genres was provided. However, after giving them a topic, they were supposed to write it by means of their PCs, laptops, tablets, cell phones, etc. and send their written paragraphs to their teacher via email within three days. Then the teacher gave the corrective feedback, again on the basis of type of error and in abundance in the text, and sent the text along with the corrective notes to the learners and asked them to revise their written texts. However, in class $C$, the same procedure was going on, and they could write their paragraphs traditionally or electronically, i.e., writing on a piece of paper or typing but no corrective feedback was given to their written paragraphs.

\section{Results and Discussion}

The SPSS Pack 20.0 for Windows Software was used to organize the raw data and conduct statistical analysis. The scores were ranging from zero to twenty. Primarily, paired sample T-Test method was used to compare the pre-test and post-test scores within each group and find out whether there is any significant difference them. The findings are demonstrated in Table. 1 below:

Table1. Paired samples T-Test results (The mean difference is significant at the 0.05 level).

\begin{tabular}{|c|c|c|c|c|c|c|c|c|}
\hline \multirow{3}{*}{ Students of each class } & \multicolumn{5}{|c|}{ Paired Differences } & \multirow[b]{3}{*}{$\mathrm{t}$} & \multirow[b]{3}{*}{$\mathrm{df}$} & \multirow{3}{*}{$\begin{array}{l}\text { Sig. }(2- \\
\text { tailed) }\end{array}$} \\
\hline & \multirow[b]{2}{*}{ Mean } & \multirow{2}{*}{$\begin{array}{c}\text { Std. } \\
\text { Deviatio } \\
\mathrm{n}\end{array}$} & \multirow{2}{*}{$\begin{array}{l}\text { Std. } \\
\text { Error } \\
\text { Mean }\end{array}$} & \multicolumn{2}{|c|}{$\begin{array}{l}95 \% \text { Confidence } \\
\text { Interval of the } \\
\text { Difference }\end{array}$} & & & \\
\hline & & & & Lower & Upper & & & \\
\hline $\begin{array}{r}\text { post-test - pre- } \\
\text { test }\end{array}$ & 1.7 & 1.97 & .51 & .61 & 2.79 & 3.36 & 14 & .005 \\
\hline $\begin{array}{r}\text { post-test - pre- } \\
\text { test }\end{array}$ & 4.11 & 2.35 & .63 & 2.75 & 5.46 & 6.55 & 13 & .000 \\
\hline $\begin{array}{r}\text { post-test - pre- } \\
\text { test }\end{array}$ & .21 & .58 & .17 & -.16 & .58 & 1.24 & 11 & .241 \\
\hline
\end{tabular}


According to the findings indicated in Table.1, the effects of hand written traditional type of giving corrective feedback and electronic corrective feedback could be realized. According to the results, a significant increase from pre-test to post-test scores is found in both experimental groups since $p$ factor (sig) is less than .05 in both cases; and therefore, it seems that both types of feedback are effective. However, in the case of class $\mathrm{C}$, as control group, no significant difference was found between pre-test and post-test scores.

Meanwhile, one-way ANOVA was employed to study the obtained scores and their mean variances between groups. That is to say, by using this method, the purpose was to compare the groups on the basis of obtained scores from pretest and post-test. The results are shown in Table. 2 below:

Table 2. Mean variance results between groups (The mean difference is significant at the 0.05 level).

\begin{tabular}{|c|c|c|c|c|c|c|c|}
\hline \multicolumn{2}{|c|}{$\begin{array}{l}\text { 95\% Confidence } \\
\text { Interval }\end{array}$} & \multirow[b]{2}{*}{ Sig. } & \multirow[b]{2}{*}{$\begin{array}{l}\text { Std. } \\
\text { Error }\end{array}$} & \multirow{2}{*}{$\begin{array}{c}\text { Mean } \\
\text { Difference } \\
(\mathrm{I}-\mathrm{J})\end{array}$} & \multirow[b]{2}{*}{$\begin{array}{l}\text { (J) classes of } \\
\text { the students }\end{array}$} & \multirow[b]{2}{*}{$\begin{array}{l}\text { (I) classes of the } \\
\text { students }\end{array}$} & \multirow[b]{2}{*}{$\begin{array}{c}\text { Dependent } \\
\text { Variable }\end{array}$} \\
\hline $\begin{array}{l}\text { Upper } \\
\text { Bound }\end{array}$ & $\begin{array}{l}\text { Lower } \\
\text { Bound }\end{array}$ & & & & & & \\
\hline 1.26 & -1.71 & .92 & .60 & -.22 & class B & class $\mathrm{A}$ & \\
\hline 1.71 & -1.80 & .86 & .60 & -.31 & class $\mathrm{C}$ & class A & pre-test scores \\
\hline 1.64 & -1.45 & .98 & .63 & -.09 & & class B & class $\mathrm{C}$ \\
\hline-.34 & -2.96 & .011 & .53 & -1.65 & class B & class $\mathrm{A}$ & \\
\hline 3.26 & .64 & .002 & .53 & 1.95 & class $\mathrm{C}$ & class A & post-test scores \\
\hline 4.97 & 2.25 & .000 & .55 & 3.61 & & class B & class $\mathrm{C}$ \\
\hline
\end{tabular}

Based on the results shown in Table.2, no significant difference was found between pre-test scores of the three classes since $p$ factor (sig) between groups was more than $0.05(p>.05)$ in the case of all three comparisons. In addition to the findings of proficiency test, this finding can also support the approximate equality of the proficiency level of groups in terms of their writing skill.

However, to the post-test scores, a significant difference was found among scores of the classes; i.e., scores of class A, compared to class $\mathrm{C}$, showed significant difference due to the fact that $p$ (sig) found to be .002 , which is less than .05 $(p<.05)$. Hence, in the case of class B, significant difference was found in comparison to the control group (class C) whereas $p$ factor (sig) between these two classes found to be .000 which is repeatedly less than $.05(p<.05)$. These findings reveal that both methods (traditional and electronic corrective feedback) affect learners' writing skill positively since students who received corrective feedback through their written assignments, whether traditionally or electronically, did better on the post-test than students who did not receive corrective feedback at all. Additionally, the most important finding of this research could be explained in terms of the two experimental groups (class A, and class B); when compared with each other, significant difference was revealed whereas $p$ (sig) found to be .011, which is lower than $.05(p<.05)$; and since the mean score of class $\mathrm{B}$, where the corrective feedback was given electronically, was significantly higher than the mean score obtained in class A, in which the corrective feedback was given traditionally(mean difference $=-1.65$ ), electronic feedback seemed to be more profitable.

Based on the findings, both methods of providing learners with corrective feedback were effective, but electronic method seemed to be more effective than traditional handwritten type in developing learners' writing skill. Although some differences exist between this study and that of Sauro (2009), they are similar in that they found both methods to be effective. But Suaro (2009) has found no significant difference between two methods, while the results of this study showed electronic feedback to be more effective. In addition, the outcomes of the current study are in line with those of Koolivand and Iravani (2013), who found electronic feedback to be more effective. Similarly, Tuzi (2001) has reported that electronic feedback can affect the writing skill of the learners in a greater extent and traditional handwritten feedback is effective, but not as much as electronic type. However, the outcomes are in contrast with the findings of Matsumara and Hann (2004), who have claimed, based on their findings, that traditional handwritten feedback is more effective than electronic feedback.

In sum, this research was a comparative study which aimed to find out and compare the effectiveness of two kinds of providing students with corrective feedback (traditional handwritten and electronic corrective feedback) in the case of their written texts. The findings revealed that both methods have practically acceptable function, but electronic feedback found to be more effective than traditional handwritten type. Since this study was done in case of writing skill, further research can be suggested to investigate the usefulness of electronic feedback on other skills such as speaking, reading, and listening. Moreover, learners in various levels of proficiency can be selected as participants. 


\section{References}

Chang, N., Watson A. B., Bakerson, A. M., Williams, E.E., McGoron, X.F. \& Spitzer. B. (2012). Electronic feedback or handwritten feedback: What do undergraduate students prefer and why. Journal of Teaching and Learning with Technology, 1(1), 1-23.

Doughty, C. \& Williams, J. (1998).Pedagogical choices in focus on form. In C. Doughty \& J. Williams (Eds.), Focus on form in classroom second language acquisition. New York: Cambridge University Press.

Ellis, R., Basturkmen, H., \&Loewen, S. (2001). Learner Uptake in Communicative ESL Lessons. Language Learning, 51(2), 281-318.

Ellis, R., Sheen, Y., Murakami, M., and Takashima, T. (2008). The effects of focused and unfocused written corrective feedback in an English as a foreign language context. System, 36 (3), 353-371.

Gonza'lez-Bueno, M. (1998).The effect of electronic mail on Spanish L2 discourse. Language Learning and Technology, 1(2), $55-70$.

Koolivand, M. \&Iravani, H. (2013).The effect of receiving electronic feedback and the effect of gender on foreign language writing performance. International Journal of Language Learning and Applied Linguistics World, 4(4), 655667.

Kupelian, M. (2001).The use of email in the L2 classroom: An overview. Second Language Learning \& Teaching.Available: http://www.usq.edu.au/opacs/cllt/sllt/1-1/ Kupelian01.htm (2002, August)

Lightbown, M.P. and Spada, N. (1999). A response to Truscott's 'What's wrong with oral grammar correction. Canadian Modern Language Review, 55(4), 457-467.

Long, M. (1991). Focus on form: A design feature in language teaching methodology. In De Bot, Kees, Ginsberg, Ralph, Kramsch\& Claire (Eds.), foreign language research in cross-cultural perspective. Amsterdam: John Benjamins.

Long, M. H., \& Robinson, P. (1998). Focus on form: Theory, research, \& practice. In C. Doughty and J. Williams (Eds.), focus on form in classroom language acquisition. Cambridge, UK: Cambridge University Press.

Lyster, R. (2004). Differential effects of prompts and recasts in form-focused instruction. Studies in Second Language Acquisition, 26(3), 399-432.

Matsumura, S. \& Hann, G. (2004). Computer anxiety and students' preferred feedback methods in EFL writing. The Modern Language Journal, 88(3), 403-415.

Sauro, S. (2009).Computer-mediated corrective feedback and the development of 12 grammar. Language Learning \& Technology, 13(1), 96-120.

Tuzi, F. (2001).E-feedback's impact on ESL writers' revisions. Available: http://files.eric.ed.gov/fulltext/ED463651.pdf (2006, November)

Wang,Y. M. (1998). Email dialogue journaling in an English as a second language (ESL) reading and writing classroom. International Journal of Educational Telecommunications, 4(2/3), 263 - 287. 